\title{
Leisure-time physical activity in the vicinity of Academias da Cidade Program in Belo Horizonte, Minas Gerais State, Brazil: the impact of a health promotion program on the community
}

\section{Atividade física de lazer no território das Academias da Cidade, Belo Horizonte, Minas Gerais, Brasil: o efeito da presença de um programa de promoção da saúde na comunidade}

\author{
La actividad física de ocio en las áreas del \\ Programa Academias da Cidade, Belo Horizonte, \\ Minas Gerais, Brasil: el efecto de la presencia \\ de un programa de promoción de la salud \\ en la comunidad
}

Amanda Paula Fernandes 1,2 Amanda Cristina de Souza Andrade 1,2 Cynthia Graciane Carvalho Ramos 1,2 Amélia Augusta de Lima Friche 1,2 Maria Angélica de Salles Dias 1,2 César Coelho Xavier 2,3 Fernando Augusto Proietti 3,4 Waleska Teixeira Caiaffa 1,2

\author{
${ }^{1}$ Faculdade de Medicina, \\ Universidade Federal de \\ Minas Gerais, Belo Horizonte, \\ Brasil. \\ 2 Observatório de Saúde \\ Urbana de Belo Horizonte, \\ Belo Horizonte, Brasil. \\ 3 Faculdade de Saúde \\ e Ecologia Humana, \\ Vespasiano, Brasil. \\ ${ }^{4}$ Centro de Pesquisas René \\ Rachou, Fundação Oswaldo \\ Cruz, Belo Horizonte, Brasil. \\ Correspondence \\ A. P. Fernandes \\ Faculdade de Medicina, \\ Universidade Federal de \\ Minas Gerais. \\ Av. Alfredo Balena 190, Belo \\ Horizonte, MG 30130-100, \\ Brasil. \\ amandapaula.fernandez@ \\ gmail.com
}

\begin{abstract}
This study analyzed leisure-time physical activity among 1,621 adults who were non-users of the Academias da Cidade Program in Belo Horizonte, Minas Gerais State, Brazil, but who lived in the vicinity of a fitness center in operation (exposed Group I) or in the vicinity of two sites reserved for future installation of centers (control Groups II and III). The dependent variable was leisure-time physical activity, and linear distance from the households to the fitness centers was the exposure variable, categorized in radial buffers: <500m; 500-1,000m; and 1,000-1,500m. Binary logistic regression was performed with the Generalized Estimation Equations method. Residents living within $<500 m$ of the fitness center gave better ratings to the physical environment when compared to those living in the 1,000 and 1,500m buffers and showed higher odds of leisure-time physical activity $(O R=1.16$; 95\%CI: 1.03-1.30), independently of socio-demographic factors; the same was not observed in the control groups (II and III). The findings suggests the program's potential for influencing physical activity in the population living closer to the fitness center and thus provide a strategic alternative for mitigating inequalities in leisure-time physical activity.
\end{abstract}

Leisure Activities; Motor Activity; Program Evaluation; Urban Health

\section{Resumo}

O estudo investigou a atividade física no lazer de 1.621 adultos não-usuários do Programa Academias da Cidade de Belo Horizonte, Minas Gerais, Brasil, e de residentes no entorno de um polo do Programa, Grupo Intervenção (Grupo I), e de dois polos com locais reservados para sua construção, grupos sem intervenção (Grupos II e III). A variável dependente foi atividade física no lazer, e a distância euclidiana dos domicílios em relação ao polo, principal variável de exposição, foi categorizada nos buffers: < 500m; 500-1.000m; $1.000-1.500 m$. A regressão logística binária foi realizada pelo método $\mathrm{Ge}-$ neralized Estimation Equations. Residentes no raio $<500 m$ da intervenção avaliaram melhor os atributos do ambiente e, quando comparados aos residentes de 1.000-1.500m, apresentaram maior chance de serem ativos no lazer $(O R=1,16$; IC95\%: 1,03-1,30), independentemente dos fatores sociodemográficos; o mesmo não foi observado nos Grupos II e III. Os resultados sugerem a potencialidade do programa em influenciar a prática de atividade física no lazer da população residente mais próxima à intervenção sendo, portanto, estratégico na mitigação de iniquidades em atividade física.

Atividades de Lazer; Atividade Motora; Avaliação de Programas e Projetos de Saúde; Saúde Urbana 


\section{Introduction}

Physical inactivity is a major risk factor for overall mortality. Health promotion policies recommend regular physical activity to prevent and control chronic non-communicable diseases, especially metabolic and cardiovascular diseases 1 . In Brazil, where chronic diseases are the leading cause of mortality 2 , only $22.5 \%$ of the population comply with the recommendations for leisuretime physical activity ${ }^{3}$.

Urbanization contributes partially to this unfavorable scenario. In the urban dynamics, problems such as lack of facilities for sports and recreation, pollution, high-density traffic, and violence tend to discourage physical activity 4 . These problems are even more complex in lowincome areas 5,6, where the lack of urban planning and infrastructure limit such activities 7. Approximately $80 \%$ of Brazilians now live in cities, and $6 \%$ of the country's population lives in areas with urban sprawl 8 .

Adopting an active lifestyle is not merely a deliberate choice, but a multifactor behavior influenced by interaction between individual characteristics and the physical, social, and political environment 7,9. Designing programs to deal with physical inactivity should address not only inequalities in access but also planning and reshaping urban space 4 . Community-based improvements in the physical environment can thus help increase the population's levels of physical activity 4,7,10.

Community-based fitness centers are intervention model, or community-based exercise training, has already been planned and designed in public policies at the Federal level in Brazil 11,12,13. In 2006, Belo Horizonte (capital of Minas Gerais State), launched the program called "Academias da Cidade" (ACP), that offer to the population free physical activity classes in public places aiming to encourage the adoption of healthhy lifestyles 14 . There are currently some 60 such centers distributed across the city's nine administrative districts 15 .

Although these community-based fitness centers are a promising strategy for promoting physical activity, the available evidence is insufficient to determine their effectiveness. The studies are mostly limited to participants in the program, and the impact on the health of the surrounding community has still not been measured 13,16,17.

The current study aimed to evaluate the impact of the ACP in Belo Horizonte on leisuretime physical activity of non-ACP users residing in households located at various distances from the community-based fitness centers. The hypothesis is that installing community-based pro- gram in low-income urban neighborhoods favors physical activity among all nearby residents, and not only participants in the program.

\section{Methods}

\section{Study design}

The data in this study come from the household survey called The BH Health Study (2008-2009), conducted by the Belo Horizonte Observatory for Urban Health (OSUBH), in two of the city's nine health districts: Oeste and Barreiro. These two districts were selected because at the time of the survey, one ACP was already operational and three others had sites reserved for future installation $13,18,19$.

As the strategy to guarantee the representativeness of residents around the ACP sites, including users and non-ACP users, the likelihood of selecting each census tract was determined according to the geographic position of these four centers. The two census tracts closest to the ACP were included in the study, without the need for random selection. Those within 500 meters and those between 500 and 1,000 meters from the ACP had 8 and 4 times higher probability of being selected, compared to census tracts more than 1,000 meters from a gym. This design allowed creating a baseline to evaluate the program's impact 13,18,19.

The sample design was proportional threestage cluster, stratified according to the Health Vulnerability Index (HVI) 20. The following were selected within each HVI stratum: (a) 149 census tracts with sample size proportional to the total number of tracts in the stratum and with the above-mentioned probabilities of being selected; (b) households, through simple random sampling from the database of the Belo Horizonte City Government; and (c) an adult resident $(\geq 18$ years) selected randomly from each household 21 , producing a total sample of 4,048 individuals. In addition, at the time of the survey, all users of the ACP already in operation were interviewed $(\mathrm{n}=319)$.

\section{Academias da Cidade Program}

In 2005, with the aim of developing comprehensive activities to prevent risk factors for chronic diseases, the Belo Horizonte City Health Secretariat implemented the ACP beginning in December 2006, with the first center built on the east side of the city 13. Between 2007 and 2008, building and planning new centers expanded the program to other areas of the city 14 . The four 
gyms included in the sample design of The $B H$ Health Study are part of this process, and one of them was inaugurated while the survey was being planned. This ACP operated in a recreational and sports center that was built in response to a collective demand by local residents and was funded through the "Participatory Budget" process 22,23.

ACP are spaces with infrastructure for physical exercise supervised by physical eduaction teachers. The activities include a physical examination, gym classes, walking, and stretch exercises, among others. Classes are given every day in up to two shifts (morning and afternoon or evening), lasting one hour each. The program targets individuals older than 18 that are referred by community health centers, besides those that show up spontaneously. Each ACP serve an average of 400 persons and are located preferably in low-income areas, either on their own infrastructure or in those shared with other services. Strategically, the gyms are located in the vicinity of the community health centers in order to maximize their reach to the entire neighborhood through activities with the municipal schools and other public facilities and services in the area 13,14,15.

\section{Study sample}

The current study used a sub-sample of 1,712 adults non-ACP users, out of the total sample of 4,048 participants of The BH Health Study (2008200). The study subjects lived in 62 census tracts within a radial buffer created by drawing a circle with 1,500 Euclidean radius meters around the ACP sites. The census tracts distributed around the ACP that was already in operation, located in the Barreiro health district, is referred to as Pole I in this study. Around the sites reserved for two other centers planned for the Barreiro and Oeste health districts are reffered as Pole II and III. The fourth center, included in the sampling process in the entire survey, was removed from this analysis because the site was initially planned for installing a center was later changed. The exposed area was thus defined as the radial buffer of the ACP already in operation (Pole I), and two unexposed areas (Pole II and III).

A 1,500-meter radial buffer was drawn from the active ACP, based on information that most of the program users lived in this area (Figure 1). The sites for future construction of Poles II and III had already been reserved by the Belo Horizonte City Health Department, so that it was also possible to draw a radial buffer from each of these two geographic points.

\section{Stratification variable}

Three groups were created for comparison: (a) Group I, which included the residents in the vicinity of Pole I, considered the group exposed to the ACP; (b) Groups II and III, consisting respectively of the residents in the vicinity of Poles II and III unexposed to the intervention. Thus, one group was exposed to the active gym in Pole I, and the other groups were not exposed to the intervention, since Poles II and III had still not been installed.

\section{Outcome variable}

The outcome was leisure-time physical activity score measured by the long version of the International Physical Activity Questionnaire (IPAQ). It was obtained by multiplying the frequency (days/week) and mean duration (minutes/day) of walking any light, moderate, and vigorous exercise reported. The latter was multiplied by two. Active individuals were defined as those with a physical activity score $\geq 150$ minutes/week 24,25 .

\section{Independent variables}

The main independent variable was the radial buffer measured as the Euclidean radius from ACP (or site for future installation), categorized as $<500$ meters, 500-1,000 meters, and 1,0001,500 meters.

The following socio-demographic variables were analyzed: gender, age (18-29; 30-39; 40-49; $50-59 ; \geq 60$ years), schooling $(0-8 ; 9-11$; and $\geq 12$ years), family income $(<2 ; 2-3 ; 3-5 ; \geq 5$ minimum wages), marital status (with or without partner), time living in the neighborhood (1-4; 5-14, 15-25; $\geq 26$ years living in the same place). Income in the census tract was obtained by the ratio between the total nominal monthly income of the permanent private households and the total population in each census tract 8 , classified in tertiles, as low, medium, and high.

Variables in the physical and social environment included the following questions and their measurement: "In your neighborhood, how would you rate the following: street lighting?" "street and sidewalk maintenance?" "public sports and recreational areas?", measured on a five-item Likert scale (very good to very bad); "Is it easy to walk from one place to another?", "Do you often see people exercising (taking walks, bicycling, playing ball)?", with dichotomous answers (yes/no), and finally, social support for physical exercise, with the question "Do you have at least one friend or family member that's committed to exercising with you?", also with dichotomous (yes/no) answers. 
Figure 1

Census tracts within a radial buffer of 1,500 meters from Academias da Cidade Program (ACP) or future sites of the program in the Oeste and Barreiro health districts, Belo Horizonte, Minas Gerais State, Brazil, according to scores on the Health Vulnerability Index.

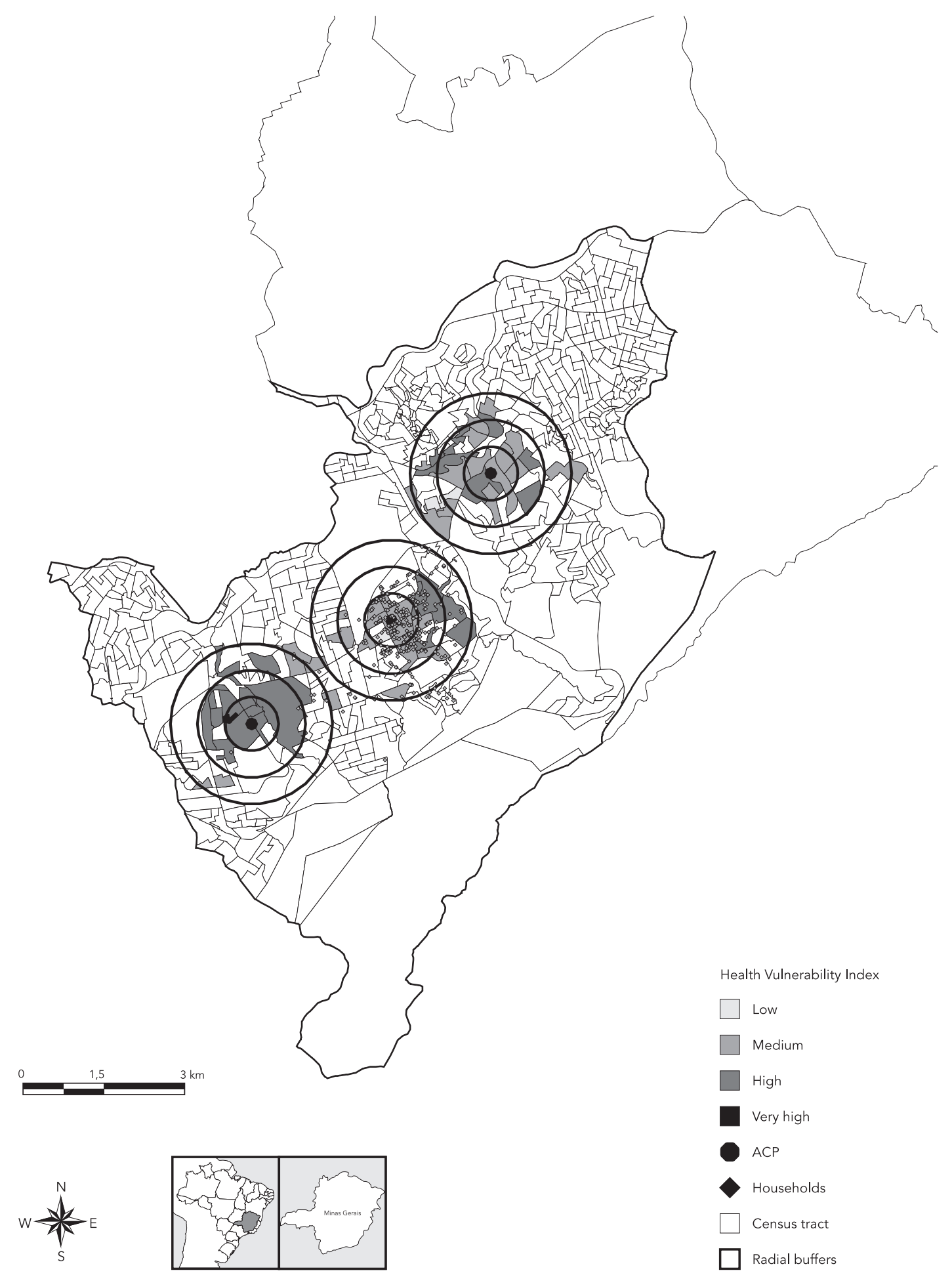




\section{Statistical analysis}

A descriptive analysis was performed, followed by calculation of the prevalence rates for leisure-time physical activity and respective $95 \%$ confidence intervals $(95 \% \mathrm{CI})$, according to each group's socio-demographic characteristics for comparison. Pearson's chi-square test was used to compare the proportions between groups and verify factors associated with leisure-time physical activity. Distribution of variables in the environment was depicted graphically based on the radial buffer from ACP (or site) for each group in the comparison.

The association between leisure-time physical activity and proximity to ACP (or site), adjusted by socio-demographic variables, used binary logistic regression with the Generalized Estimation Equations (GEE) method, which considers cluster effect (individuals nested in the census tract). An exchangeable correlation structure was used, appropriate when the observations are grouped in some specific structure 26 . The magnitude of the association was estimated by the odds ratio (OR) and respective 95\%CI. Significance was set at $5 \%$.

The analyses were performed in Stata 12.0 (StataCorp LP, College Station, USA). Geographic data were processed with MapInfo 8.5 (MapInfo Corp., New York, USA).

The study was approved by the Ethics Research Committee of Universidade Federal de Minas Gerais (COEP - case review n. ETIC 253/006).

\section{Results}

Of the 1,712 participants in the study, $5.6 \%$ were excluded due to lack of information on the response variable, totaling 1,621 adults. Of these, there were 519 individuals in Group I, 422 in Group II, and 680 in Group III, distributed in 20, 17 , and 25 census tracts, respectively.

As for socio-demographic characteristics, there were more females, individuals with 0 to 8 years of schooling, and those with a partner in all three groups, with no statistically significant difference. The groups differed in age, family income, time in the neighborhood, and mean income of the census tract. Mean age was 43.8 years (95\%CI: 42.4-45.2) in Group I, 40.2 (95\%CI: 38.641.7 ) in Group II, and 45.5 (95\%CI: $44.2-46.7$ ) in Group III. Group II had the lowest proportion of individuals with family income $\geq 5$ minimum wages (15.2\% versus $20.3 \%$ in Group I and $23.3 \%$ in Group III). Mean time living in the neighborhood in Group III (17.5 years; 95\%CI: 16.5-18.6) was greater than in the other groups (14.5 years; 95\%CI: 13.5-15.5 Group I and 14.3 years; $95 \% \mathrm{CI}$ : 13.4-15.2 Group II). Groups I and III had $73 \%$ and $43 \%$ of the residents in middle-income tracts, respectively, while in Group II, 77\% lived in lowincome tracts.

As for the physical and social environment, there was no difference between the groups, and the majority gave very good or good ratings to street lighting and street and sidewalk maintenance, and reported seeing people exercising in the neighborhood. However, there was a difference between the groups in: rating of sports/ recreational areas, since $65.1 \%$ of those living around the installed center (Group I) gave very good or good ratings, as compared to $27 \%$ in Group II and $24.8 \%$ in Group III. Ease in walking around the neighborhood was greater in Group III (94.3\% versus $87.5 \%$ in Group I and $87.7 \%$ in Group II). More individuals in Group I received social support for physical exercise from friends and family (Table 1).

Prevalence of leisure-time physical activity was $26.6 \%$ (95\%CI: 22.7-30.4) in Group I, $22.3 \%$ (95\%CI: 18.3-26.2) in Group II, and 23.2\% (95\%CI: 20.0-26.4) in Group III ( $\mathrm{p}=0.246)$. Walking was the most common activity among those that reported physical activity in the three months prior to the interview, with $64.1 \%$ in Group I, $59.8 \%$ in Group II, and 56.6\% in Group III ( $p=0.293$ ). Gender and age were only associated with leisuretime physical activity in Group I, with a higher prevalence of active men and young individuals. Individuals with more schooling in the three groups and with higher family income in Groups II and III were more physically active. Mean income in the census tract was associated with more leisure-time physical activity in Groups I and III (Table 2).

The prevalence of active individuals was higher among residents closest to Pole I $(32.1 \%$ for a distance $<500 \mathrm{~m} ; 25.4 \%$ from 500 to $1,000 \mathrm{~m}$, and $16.3 \%$ from 1,000 to $1,500 \mathrm{~m}$ ). As shown in Table 2, for the groups without the intervention (II and III) there was no such trend nor significant difference.

Figure 2 shows the distribution of characteristics in the physical and social environment based on radial buffers from ACP (or future sites). People living within 500m radial buffer from the installed center (Group I) were more likely to rate the sports and recreational areas and street and sidewalk maintenance as very good or good. They were also more likely to see people exercising in the neighborhood, where it is easy to walk around, and to report social support encouragement from friends and family.

As shown in Table 3, the positive association 
Distribution of socio-demographic characteristics and ratings of the physical and social environment in neighborhoods with and without Academias da Cidade Program. Belo Horizonte, Minas Gerais State, Brazil, 2008-2009.

\begin{tabular}{|c|c|c|c|c|}
\hline & Group I * (\%) & Group II (\%) & Group III (\%) & $\mathrm{p}$-value ** \\
\hline \multicolumn{5}{|l|}{ Socio-demographic } \\
\hline Gender (female) & 63.8 & 60.2 & 57.8 & 0.110 \\
\hline \multicolumn{5}{|l|}{ Age (years) } \\
\hline $18-29$ & 23.5 & 33.2 & 20.7 & $<0.001$ \\
\hline $30-39$ & 19.7 & 21.1 & 20.3 & \\
\hline $40-49$ & 20.6 & 16.8 & 19.6 & \\
\hline $50-59$ & 18.9 & 15.4 & 16.3 & \\
\hline$\geq 60$ & 17.3 & 13.5 & 23.1 & \\
\hline \multicolumn{5}{|l|}{ Schooling *** (years) } \\
\hline $0-8$ & 49.3 & 53.2 & 51.6 & 0.142 \\
\hline $9-11$ & 37.4 & 38.5 & 35.8 & \\
\hline$\geq 12$ & 13.3 & 8.3 & 12.5 & \\
\hline \multicolumn{5}{|l|}{ Family income ${ }^{\star \star \star}$ (times minimum wage \#) } \\
\hline$<2$ & 26.2 & 36.1 & 28.2 & 0.004 \\
\hline $2-3$ & 27.8 & 26.2 & 24.1 & \\
\hline $3-5$ & 25.8 & 22.5 & 24.4 & \\
\hline$\geq 6$ & 20.3 & 15.2 & 23.3 & \\
\hline Conjugal status (with partner) & 56.8 & 55.0 & 54.4 & 0.693 \\
\hline \multicolumn{5}{|l|}{ Time living in neighborhood *** (years) } \\
\hline $1-4$ & 27.6 & 23.8 & 25.8 & $<0.001$ \\
\hline $5-14$ & 27.9 & 26.1 & 20.6 & \\
\hline $15-25$ & 27.7 & 37.3 & 23.6 & \\
\hline$\geq 26$ & 16.8 & 12.8 & 30.0 & \\
\hline \multicolumn{5}{|l|}{ Mean income in census tract $\star \star \star ~$} \\
\hline Low & 23.9 & 77.0 & 35.6 & $<0.001$ \\
\hline Medium & 73.0 & 23.0 & 46.1 & \\
\hline High & 3.1 & 0.0 & 18.3 & \\
\hline \multicolumn{5}{|l|}{ Physical and social environment } \\
\hline 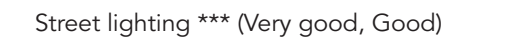 & 83.6 & 83.6 & 82.6 & 0.874 \\
\hline 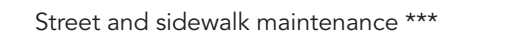 & 69.9 & 63.7 & 67.1 & 0.125 \\
\hline \multicolumn{5}{|l|}{ (Very Good/Good) } \\
\hline Public sports/recreational areas *** (Very & 65.1 & 27.0 & 24.8 & $<0.001$ \\
\hline \multicolumn{5}{|l|}{ Good/Good) } \\
\hline 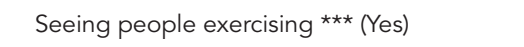 & 77.9 & 79.1 & 78.4 & 0.899 \\
\hline Ease in walking around $* \star \star$ (Yes) & 87.5 & 87.7 & 94.3 & $<0.001$ \\
\hline Social support from friends /family *** (Yes) & 71.4 & 65.3 & 64.1 & 0.021 \\
\hline
\end{tabular}

* Exposed group;

** Pearson's chi-square test;

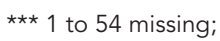

\# Minimum wage: BRL 415.00.

between leisure-time physical activity and proximity to the ACP in the exposed group (model 1 ) is maintained even after adjusting for sociodemographic characteristics (model 2), as well as for mean income in the census tract (model 3 ). Compared to people within 1,000-1,500m radial buffer from the Pole I, those living closer to it showed higher odds of being active in their leisure time $(\mathrm{OR}=1.16$; 95\%CI: $1.03-1.30$ for $<$ $500 \mathrm{~m}$ and $\mathrm{OR}=1.06$; $95 \% \mathrm{CI}: 0.88-1.57$ for 500 to $1,000 \mathrm{~m})$. 
Prevalence of leisure-time physical activity according to socio-demographic variables and radial buffers around Academias da Cidade Program (ACP) or future sites of the program. Belo Horizonte, Minas Gerais State, Brazil, 2008-2009.

\begin{tabular}{|c|c|c|c|c|c|c|}
\hline & \multicolumn{2}{|c|}{ Group I * } & \multicolumn{2}{|c|}{ Group II } & \multicolumn{2}{|c|}{ Group III } \\
\hline & $\%(95 \% \mathrm{Cl})$ & $\mathrm{p}$-value ** & $\%(95 \% \mathrm{Cl})$ & $\mathrm{p}$-value ** & $\%(95 \% \mathrm{Cl})$ & $\mathrm{p}$-value ** \\
\hline \multicolumn{7}{|l|}{ Gender } \\
\hline Male & $31,4(24.7-38.0)$ & 0.062 & $30.4(23.4-37.4)$ & 0.001 & $26.1(21.0-31.2)$ & 0.126 \\
\hline Female & $23.9(19.3-28.5)$ & & $16.9(12.3-21.6)$ & & $21.1(17.1-25.2)$ & \\
\hline \multicolumn{7}{|l|}{ Age (years) } \\
\hline $18-29$ & $28.7(20.6-36.8)$ & 0.266 & $32.1(24.4-39.9)$ & 0.009 & $31.2(23.5-26.2)$ & 0.130 \\
\hline $30-39$ & $18.6(11.0-26.2)$ & & $15.7(8.1023 .4)$ & & $19.6(12.9-26.2)$ & \\
\hline $40-49$ & $29.9(21.1-38.6)$ & & $16.9(8.1-25.7)$ & & $19.5(12.8-26.3)$ & \\
\hline $50-59$ & $30.6(21.4-39.8)$ & & $23.1(12.7-33.4)$ & & $22.5(14.7-30.3)$ & \\
\hline$\geq 60$ & $24.4(15.5-33.4)$ & & $14.0(4.9-23.2)$ & & $22.9(16.3-29.5)$ & \\
\hline \multicolumn{7}{|l|}{ Schooling (years) } \\
\hline $0-8$ & $24.6(19.3-29.9)$ & 0.040 & $16.1(11.2-20.9)$ & 0.004 & $17.7(13.7-21.7)$ & 0.002 \\
\hline $9-11$ & $24.7(18.6-30.8)$ & & $30.3(23.1-37.4)$ & & $28.0(22.3-33.6)$ & \\
\hline$\geq 12$ & $39.1(27.5-50.8)$ & & $22.9(8.7-37.0)$ & & $31.8(21.8-41.7)$ & \\
\hline \multicolumn{7}{|c|}{ Family income (times minimum wage ${ }^{\star \star \star}$ ) } \\
\hline$<2$ & $18.8(12.1-25.5)$ & 0.076 & $14.1(8.5-19.7)$ & 0.006 & $23.0(16.9-29.1)$ & $<0.001$ \\
\hline $2-3$ & $31.9(24.2-39.7)$ & & $21.2(13.5-29.1)$ & & $10.6(5.8-15.4)$ & \\
\hline $3-5$ & $26.0(18.4-33.5)$ & & $30.1(20.7-39.5)$ & & $24.1(17.5-30.7)$ & \\
\hline$\geq 5$ & $30.1(21.1-39.0)$ & & $31.7(20.1-43.3)$ & & $35.5(27.9-43.1)$ & \\
\hline \multicolumn{7}{|c|}{ Time living in neighborhood (years) } \\
\hline $1-4$ & $23.8(16.8-30.8)$ & 0.129 & $19.0(11.2-26.8)$ & 0.457 & $19.4(13.5-25.3)$ & 0.220 \\
\hline $5-14$ & $23.4(16.5-30.4)$ & & $19.1(11.7-26.5)$ & & $21.4(14.6-28.3)$ & \\
\hline $15-25$ & $34.0(26.2-41.8)$ & & $25.5(18.6-32.3)$ & & $28.8(21.7-35.8)$ & \\
\hline$\geq 26$ & $24.1(15.1-33.2)$ & & $25.9(14.1-37.8)$ & & $23.5(17.7-29.4)$ & \\
\hline \multicolumn{7}{|c|}{ Mean income in census tract } \\
\hline Low & $19.4(12.4-26.4)$ & 0.017 & $21.8(17.3-26.4)$ & 0.698 & $18.3(13.2-23.3)$ & $<0.001$ \\
\hline Medium & $28.0(23.4-32.5)$ & & $23.7(15.2-32.2)$ & & $23.2(18.3-28.0)$ & \\
\hline High & $50.0(24.6-75.4)$ & & 0.0 & & $30.5(22.1-38.9)$ & \\
\hline \multicolumn{7}{|c|}{$\begin{array}{l}\text { Radial buffers around ACP or future sites of } \\
\text { tha program (meters) }\end{array}$} \\
\hline$<500$ & $32.1(25.8-38.3)$ & 0.014 & $18.9(11.0-26.9)$ & 0.671 & $24.8(17.4-32.1)$ & 0.689 \\
\hline $500-1,000$ & $25.4(19.4-31.3)$ & & $22.9(16.9-29.0)$ & & $21.9(17.7-26.2)$ & \\
\hline $1,000-1,500$ & $16.3(8.7-23.9)$ & & $23.6(16.4-30.6)$ & & $24.7(18.3-31.1)$ & \\
\hline
\end{tabular}

95\% Cl: 95\% confidence interval.

* Exposed group;

** Pearson's chi-square test;

*** Minimum wage: BRL 415.00

\section{Discussion}

Non-ACP users of centers who lived within 500 meters buffer zone surrounding the program reported higher odds of leisure-time physical activity when compared to those living farther away, even after adjusting for socio-demographic characteristics and mean income. This effect was not seen in areas without the intervention (with sites reserved for the ACP, but where they had not been installed). Residents living up to $500 \mathrm{~m}$ from the installed center were also more likely to give higher ratings to the area's sports and recreational facilities and other characteristics of the physical environment, in addition to reporting more social support for exercising from friends and family. 
Figure 2

Distribution of very good/good ratings for public sports and recreational areas, street lighting, and street and sidewalk maintenance, seeing people exercising, ease in walking around neighborhood, and social support from friends and family, according radial buffers, stratified by comparison groups.

2a) Public sports and recreational areas

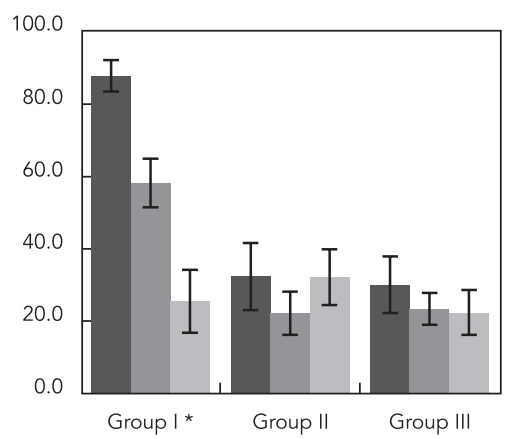

2c) Street lighting

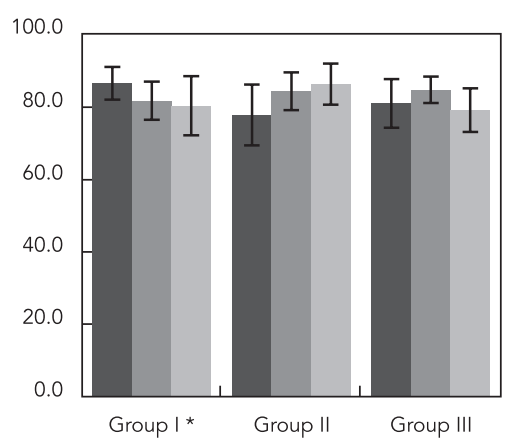

2e) Ease in walking around neighborhood

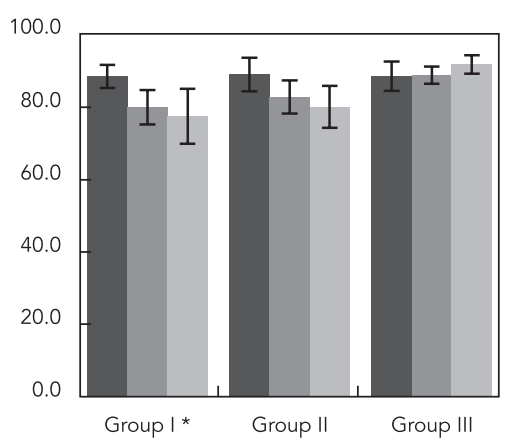

2b) Street and sidewalk maintenance

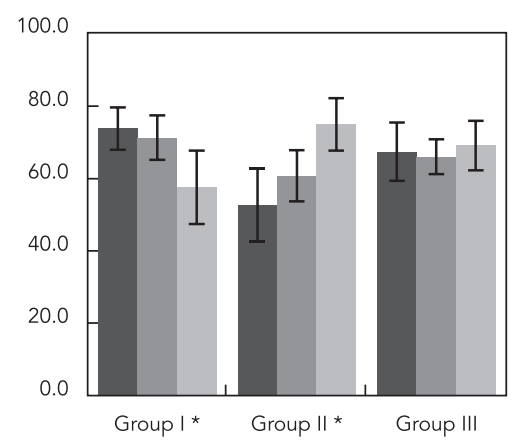

$<500 \mathrm{~m}$

500-1,000m

$1,000-1,500 \mathrm{~m}$ 2d) Seeing people exercising

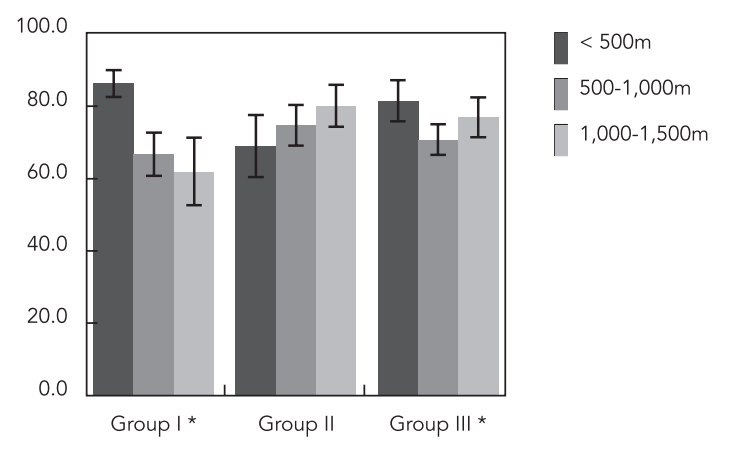

2f) Social support from friends and family

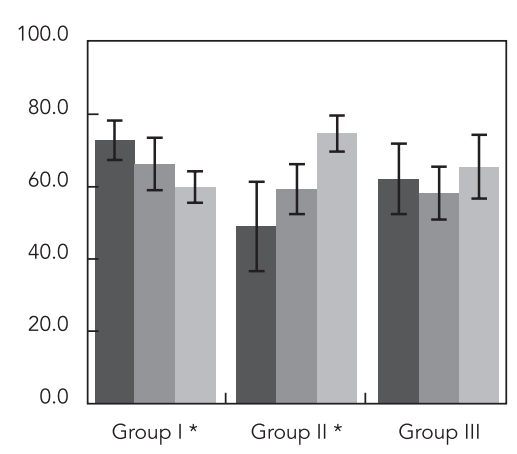

$<500 \mathrm{~m}$

500-1,000m

$1,000-1,500 \mathrm{~m}$ 500-1,000m

- $1,000-1,500 \mathrm{~m}$

${ }^{*} p<0.05$ 
Binary logistic regression model for leisure-time physical activity and radial buffers around Academias da Cidade Program (ACP) or future sites of the program. Belo Horizonte, Minas Gerais State, Brazil, 2008-2009.

\begin{tabular}{|c|c|c|c|c|}
\hline Model & Variable & $\begin{array}{c}\text { Group I * } \\
\text { OR (95\%Cl) }\end{array}$ & $\begin{array}{c}\text { Group II } \\
\text { OR (95\%Cl) }\end{array}$ & $\begin{array}{c}\text { Group III } \\
\text { OR }(95 \% \mathrm{Cl})\end{array}$ \\
\hline \multirow[t]{4}{*}{1} & Radial buffers around ACP or future sites of the program (meters) & & & \\
\hline & $<500$ & $1.19(1.05-1.34)$ & $0.95(0.84-1.07)$ & $1.00(0.91-1.10)$ \\
\hline & $500-1,000$ & $1.10(0.98-1.24)$ & $0.99(0.90-1.10)$ & $0.97(0.90-1.05)$ \\
\hline & $1,000-1,500 \mathrm{~m}$ & 1.00 & 1.00 & 1.00 \\
\hline \multirow[t]{4}{*}{2} & Radial buffers around ACP or future sites of the program (meters) & & & \\
\hline & $<500$ & $1.17(1.04-1.32)$ & $0.94(0.83-1.06)$ & $1.00(0.92-1.09)$ \\
\hline & $500-1,000$ & $1.09(0.97-1.22)$ & $0.98(0.88-1.08)$ & $0.97(0.91-1.04)$ \\
\hline & $1,000-1,500 \mathrm{~m}$ & 1.00 & 1.00 & 1.00 \\
\hline \multirow[t]{4}{*}{3} & Radial buffers around ACP or future sites of the program (meters) & & & \\
\hline & $<500$ & $1.16(1.03-1.30)$ & $0.94(0.80-1.11)$ & $0.94(0.86-1.04)$ \\
\hline & $500-1,000$ & $1.06(0.94-1.19)$ & $0.98(0.85-1.14)$ & $0.96(0.90-1.02)$ \\
\hline & $1,000-1,500 \mathrm{~m}$ & 1.00 & 1.00 & 1.00 \\
\hline
\end{tabular}

95\% $\mathrm{Cl}$ : 95\% confidence interval; OR: odds ratio.

Model 1: univariate; Model 2: adjusted for gender, age, and schooling; Model 3: adjusted for gender, age, schooling, and mean income in census tract.

* Exposed group.

The neighborhood or housing context combines characteristics that represent different lifestyle opportunities $6,27,28$. The way the environment is shaped with equipment, infrastructure, services, and public spaces has been increasingly identified as a modulator of health-related habits $9,29,30,31$. From this perspective, it is possible that a community-based physical activity program impacts its surroundings and to a certain extent affects the daily lives of the area's residents.

Previous assessments in some Brazilian State capitals suggest a positive influence from ACP on the physical activity of non-users, translated as the indirect effect of having seen or heard of the program 32,33 . However, none of these studies compared groups with and without such interventions or assessed the association between physical activity and distance to the centers. There are also reports that the ACP's visual identity is one of the main mechanisms for publicizing the program among the overall population 33,34.

In our study, in the exposed group (I), the prevalence of physical acitivty among non-ACP users showed a dose-response gradient according to the proximity to the center. It is plausible to argue that physical and social factors in the neighborhood could be favorable physical activity in non-ACP users residents.

Thus, the creation of public spaces based on linking urban and social policies like the ACP foster alternatives in the daily lives of all local residents for overcoming the barriers involved in physical inactivity. In other words, at the intermediate level the ACPs could modify the context's characteristics and act indirectly on more proximal factors related to leisure-time physical activity $5,7,9,27$.

This hypothesis is reinforced by the positive ratings given to the neighborhood's physical attributes, more common among people living closer to the Pole I (radial buffer $<500 \mathrm{~m}$ ). Public sites for sports and recreation, as well as street and sidewalk maintenance, were rated better by those living within a shorter radial buffer from the Pole I when compared to those living more than 500m from it. Proximity to the program was also associated with reports of greater ease in walking around and seeing more people exercising in the neighborhood. As the radial buffer from the Pole I increased, the positive perception of these neighborhood characteristics decreased significantly. For non-exposed groups (II and III) this analysis by proximity did not show the same gradient. The presence of the ACP (Pole I) in a neighborhood that had never had a similar facility 23 resulted to an important change in the physical environment and may have produced the differences in leisure-time physical activity observed in the radial buffer around the Pole I.

When we analyzed the barriers to leisuretime physical activity among inactive individuals in the three months prior to the interview 
(data not shown), lack of time (51.4\% Group I, 48.3\% Group II, and 54.9\% Group III, p = 0.212) and lack of access to center equipment $(33.4 \%$ Group I, 38.2\% Group II, and 36.9\% Group III, p = 0.304 ) were the most frequently cited reasons in the three groups. However, the stratified analysis by proximity showed that $23.8 \%$ of the residents closest to Pole I reported not having access to center equipment, compared to $41.7 \%$ of those living within 500 to $1,000 \mathrm{~m}$ radial buffer away and $35.9 \%$ in those living 1,000 to $1,500 m$ away ( $p=0.008$ ). Equivalent results were not found in the comparator groups. Proximity to a public space for physical exercise may have contributed to these results, since it is an important factor for encouraging leisure-time physical activity 7,10.

Social support from friends and family was also greater in Group I, and again the gradient suggested the effect of proximity to the intervention. Group II, the most economically deprived area, showed an inverse gradient, and in Group III there was no association between proximity and social support for exercise. The center may facilitate and encourage awareness-raising on the benefits of leisure-time physical activity. This network of information could be further enhanced by the presence of the program's users in the neighborhood ${ }^{34}$. The ACP structure at Pole I might increase the likelihood of social contacts among the area's residents and reinforce social support for physical activity.

As far as we know, this is the first study on the effect of ACP on leisure-time physical activity among non-ACP users, based on different proximity from the ACP equipment and including comparator groups (without the intervention). Some limitations should be discussed. Since it was impossible to obtain information from the neighborhood residents before the first ACP (Pole I) was installed, no causal relationship can be inferred over time. Meanwhile, the gradient observed in different analyses of the radial buffers from the ACP sites reinforces the plausibility of the findings and the direction of the association.

The selection of only one center in operation and two planned for future installation limits any generalization of the findings. However, the sampling design of the overall survey attempted to guarantee the representativeness of gym users and the surrounding population in general $13,18,19$. Although the variables are subject to the influence of individual characteristics such as income, schooling, or age 35 , ratings of the physical environment were validated for the same population sample 36 . The use of self-reported information to measure leisure-time physical activity is subject to under- and overestimation of the duration and intensity of exercise. However, the questionnaire had been previously validated for the Brazilian population 37 .

As for the use of circular radial buffers from the ACP as the principal independent variable, while it does not represent the residents' actual mobility to access the centers sites, it does provide an objective measure capable of avoiding the limitations of self-reported data. Circular buffers based on Euclidean radius, even ignoring physical barriers or available ways of access, increases the odds of more homogeneous distribution of the exposure 35,38 . This strengthens the data's internal validity and minimizes possible common source biases.

Despite the limitations, the findings suggest that the impact of a health promotion program physical activity can produce effects beyond its direct participants, affecting the entire community. The inference is that ACP intervenes in the setting, producing a "halo" effect that expands with potential reach to those closest to the intervention. This effect can be nonlinear, unanticipated, big or small in each specific context 6,27 . In terms of effectiveness, these findings signal the ability of the ACP to expand their action and become an epicenter for health promotion.

The findings of this study can have an important practical implications given the current expansion of the model at the entire country 11,39 and the role of ACP in primary care 14 . By definition, the program is a locus for health promotion and should thus play a key role for the population as a whole in collectively and autonomously achieving health 40 .

The available literature shows that ACP attract well-defined groups of users (women, elderly, chronic diseases patients, and lower-income individuals) and thus allow physical exercise for groups with few such opportunities 13,41. Thus, having designed a strategic program to mitigate inequalities in physical activity, the questions arises concerning the program's impact at the overall population level 42,43 . However, by prioritizing the installation of centers in low-income urban areas and with a possible effect on the entire neighborhood, as shown in this study, the program can contribute to equity in the benefits of access to physical activity.

As in any urban intervention, ACP involve complex and multifaceted components 44 . To shed light on the program's effectiveness, including in other urban contexts, impact assessments should include more centers to make the samples more robust, pre- and post-installation studies, and other analytical methods such as propensity score matching, which allow controlling for potential confounding between the exposure and outcome in observational studies. 


\section{Resumen}

El estudio investigó la actividad física de ocio de 1.621 adultos, como usuarios del Programa Academias da Cidade de Belo Horizonte, Minas Gerais, Brasil, y residentes en las proximidades de una zona con presencia del Programa, con un grupo de intervención (Grupo I), y dos zonas con espacios reservados para su construcción, así como grupos no-intervención (Grupos II y III). La variable dependiente fue la actividad física de ocio y la distancia euclidiana de los hogares en relación con la zona; la variable de exposición principal fue categorizada en buffers: < 500; 500-1.000m; 1.000-1.500m. Se utilizó la regresión logística binaria por ecuaciones de estimación generalizadas. Los residentes en el buffer < $500 \mathrm{~m}$ de la intervención evaluaron mejor los atributos del medio ambiente y, en comparación con los residentes 1.000-1.500m, eran más propensos a ser activos en su tiempo libre (OR = 1,16; IC95: 1,03-1,30), independientemente de los factores socio-demográficos; la misma asociación no fue observada en los Grupos II y III. Los resultados sugieren el potencial del programa para influir en la práctica de actividad física de ocio de la población más cercana a la intervención.

Actividades Recreativas; Actividad Motora; Evaluación de Programas y Proyectos de Salud; Salud Urbana

\section{Contributors}

A. P. Fernandes, A. C. S. Andrade, and C. G. C. Ramos contributed to the literature review, data analysis, and writing of the article. A. A. L. Friche contributed to the literature review, data analysis, and revision of the final version. M. A. S. Dias collaborated in the revision of the article's final version. C. C. Xavier and F. A. Proietti collaborated in the project development and revision of the final version. W. T. Caiaffa contributed to the project's development, conceptualization of the study, literature review, data analysis, and writing of the article.

\section{Acknowledgments}

The authors wish to acknowledge all the researchers at the Belo Horizonte Observatory for Urban Health who participated in The BH Health Study as well as the support from the Secretaria Municipal de Saúde de Belo Horizonte during the data collection. We thank Fernando Marcio Freire, specialist in strategic resources at Empresa de Informática e Informação do Município de Belo Horizonte (PRODABEL), and Professor Hugo Cesar Martins Costa of Pontifícia Universidade Católica de Minas Gerais. We also wish to thank the Brazilian National Research Council (CNPq) for providing research grants to W. T. Caiaffa and F. A. Proietti.

\section{References}

1. World Health Organization. Global strategy on diet, physical activity and health. Geneva: World Health Organization; 2004.

2. Schmidt MI, Duncan BB, Azevedo e Silva G, Menezes AM, Monteiro CA, Barreto SM, et al. Chronic non-communicable diseases in Brazil: burden and current challenges. Lancet 2011; 377:1949-61.

3. Instituto Brasileiro de Geografia e Estatística. Pesquisa Nacional de Saúde, 2013. Percepção do estado de saúde, estilos de vida e doenças crônicas: Brasil, Grandes regiões e Unidades da Federação. Rio de Janeiro: Instituto Brasileiro de Geografia e Estatística; 2014.
4. World Health Organization. Promoting physical activity and active living in urban environments. Geneva: World Health Organization; 2006.

5. Caiaffa WT, Ferreira FR, Ferreira AD, Oliveira CD, Camargos VP, Proietti FA. Urban health: "the city is a strange lady, smiling today, devouring you tomorrow". Ciênc Saúde Coletiva 2008; 13:1785-96.

6. Galea S, Vlahov D. Urban health: evidence, challenges, and directions. Annu Rev Public Health 2005; 26:341-65.

7. Bauman AE, Reis RS, Sallis JF, Wells JC, Loos RJ, Martin BW, et al. Correlates of physical activity: why are some people physically active and others not? Lancet 2012; 380:258-71. 
8. Instituto Brasileiro de Geografia e Estatística. Sinopse do Censo Demográfico 2010. Rio de Janeiro: Instituto Brasileiro de Geografia e Estatística; 2011.

9. Sallis JF, Cervero RB, Ascher W, Henderson KA, Kraft MK, Kerr J. An ecological approach to creating active living communities. Annu Rev Public Health 2006; 27:297-322.

10. Rydin Y, Bleahu A, Davies M, Davila JD, Friel S, De Grandis G, et al. Shaping cities for health: complexity and the planning of urban environments in the 21st century. Lancet 2012; 379:2079-108.

11. Ministério da Saúde. Portaria no 719, de 7 de abril de 2011. Institui o Programa Academia da Saúde no âmbito do Sistema Único de Saúde. Diário Oficial da União 2011; 8 abr.

12. Malta DC, Castro AM, Gosch CS, Cruz DKA, Bressan A, Nogueira JD, et al. A Política Nacional de Promoção da Saúde e a agenda da atividade física no contexto do SUS. Epidemiol Serv Saúde 2009; 18:79-86

13. Secretaria de Vigilância em Saúde, Ministério da Saúde. Avaliação de efetividade de Programas de Atividade Física no Brasil. Brasília: Ministério da Saúde; 2011.

14. Dias MAS, Bicalho K, Mourão M, Alves MN, Evangelista PA, Rodrigues RCLC, et al. Promoção à saúde e articulação intersetorial. In: Magalhães Júnior HM, organizador. Desafios e inovações na gestão do SUS em Belo Horizonte: a experiência de 2003 a 2008. Belo Horizonte: Mazza; 2010. p. 63-99.

15. Prefeitura de Belo Horizonte. Academia da Cidade: saúde e equilíbrio mais próximo do cidadão. http://portalpbh.pbh.gov.br/pbh/contents.do?ev ento $=$ conteudo\&idConteudo $=26825 \&$ chPlc $=26825$ (accessed on Jul/2014).

16. Hoehner CM, Ribeiro IC, Parra DC, Reis RS, Azevedo MR, Hino AA, et al. Physical activity interventions in Latin America: expanding and classifying the evidence. Am J Prev Med 2013; 44:e31-40.

17. Hoehner CM, Soares J, Parra Perez D, Ribeiro IC, Joshu CE, Pratt M, et al. Physical activity interventions in Latin America: a systematic review. Am J Prev Med 2008; 34:224-33.

18. Camargos VP, Cesar CC, Caiaffa WT, Xavier CC, Proietti FA. Multiple imputation and complete case analysis in logistic regression models: a practical assessment of the impact of incomplete covariate data. Cad Saúde Pública 2011; 27:2299-313.

19. Ferreira AD, Comini CC, Malta DC, Andrade ACS, Ramos CGC, Proietti FA, et al. Validity of data collected by telephone survey: a comparison of VIGITEL 2008 and 'Saúde em Beagá' survey. Rev Bras Epidemiol 2011; 14:16-30.

20. Caiaffa WT, Nabuco AL, Friche AAL, Proietti FA. Urban health and governance model in Belo Horizonte, Brazil. In: Vlahov D, Boufford JI, Pearson C, Norris L, editors. Urban health: global perspective. New York: The New York Academy of Medicine; 2010. p. 437-52.

21. Berquó ES. Selección de unidades de información en encuestas demográficas: un método para construir tablas de sorteo. Santiago de Chile: Centro Latinoamericano y Caribeño de Demografía; 1975. (Notas de Población, 3).
22. Prefeitura de Belo Horizonte. Plano de empreendimentos. Orçamento participativo 2009/2010. http://www.pbh.gov.br/comunicacao/pdfs/publi cacoesop/caderno_empreendimentos_op_2009_ 2010.pdf (accessed on Jul/2014).

23. Prefeitura de Belo Horizonte. Obras de ontem na Regional Barreiro. http://portalpbh.pbh.gov.br/ $\mathrm{pbh} / \mathrm{ecp} /$ noticia.do? evento $=$ portlet $\& \mathrm{pAc}=$ not\&id Conteudo $=48971$ (accessed on Jul/2014).

24. World Health Organization. Global recommendations on physical activity for health. Geneva: World Health Organization; 2010.

25. Departamento de Análise de Situação de Saúde, Secretaria de Vigilância em Saúde, Ministério da Saúde. Vigitel Brasil 2012: vigilância de fatores de risco e proteção para doenças crônicas por inquérito telefônico. Brasília: Ministério da Saúde; 2013.

26. Hanley JA, Negassa A, Edwardes MDB, Forrester JE. Statistical analysis of correlated data using generalized estimating equations: an orientation. Am J Epidemiol 2003; 157:364-75.

27. Diez Roux AV, Mair C. Neighborhoods and health. Ann N Y Acad Sci 2010; 1186:125-45.

28. Proietti FA, Oliveira CDL, Ferreira FR, Ferreira AD, Caiaffa WT. Unidade de contexto e observação social sistemática em saúde: conceitos e métodos. Physis (Rio J.) 2008; 18:469-82.

29. Diez Roux AV. Residential environments and cardiovascular risk. J Urban Health 2003; 80:569-89.

30. Mehdipanah R, Rodriguez-Sanz M, Malmusi D, Muntaner C, Diez E, Bartoll X, et al. The effects of an urban renewal project on health and health inequalities: a quasi-experimental study in Barcelona. J Epidemiol Community Health 2014; 68:811-7.

31. Rech CR, Reis RS, Hino AA, Hallal PC. Personal, social and environmental correlates of physical activity in adults from Curitiba, Brazil. Prev Med 2014; 58:53-7.

32. Mendonca BC, Oliveira AC, Toscano JJO, Knuth AG, Borges TT, Malta DC, et al. Exposure to a community-wide physical activity promotion program and leisure-time physical activity in Aracaju, Brazil. J Phys Act Health 2010; 7 Suppl 2:S223-8.

33. Simoes EJ, Hallal P, Pratt M, Ramos L, Munk M, Damascena W, et al. Effects of a community-based, professionally supervised intervention on physical activity levels among residents of Recife, Brazil. Am J Public Health 2009; 99:68-75.

34. Hallal PC, Tenorio MC, Tassitano RM, Reis RS, Carvalho YM, Cruz DK, et al. Evaluation of the Academia da Cidade program to promote physical activity in Recife, Pernambuco State, Brazil: perceptions of users and non-users. Cad Saúde Pública 2010; 26:70-8

35. Hino AAF, Reis RS, Florindo AA. Ambiente construído e atividade física: uma breve revisão dos métodos de avaliação. Rev Bras Cineantropom Desempenho Hum 2010; 12:387-94.

36. Friche AA, Diez-Roux AV, Cesar CC, Xavier CC, Proietti FA, Caiaffa WT. Assessing the psychometric and ecometric properties of neighborhood scales in developing countries: Saude em Beaga Study, Belo Horizonte, Brazil, 2008-2009. J Urban Health 2013; 90:246-61. 
37. Craig CL, Marshall AL, Sjostrom M, Bauman AE, Booth ML, Ainsworth BE, et al. International physical activity questionnaire: 12-country reliability and validity. Med Sci Sports Exerc 2003; 35: 1381-95

38. Chaix B, Merlo J, Evans D, Leal C, Havard S. Neighbourhoods in eco-epidemiologic research: delimiting personal exposure areas. A response to Riva, Gauvin, Apparicio and Brodeur. Soc Sci Med 2009; 69:1306-10.

39. Ministério da Saúde. Portaria no 2.681, de 7 de novembro de 2013. Redefine o Programa Academia da Saúde no âmbito do Sistema Único de Saúde (SUS). Diário Oficial da União 2013; 8 nov.

40. Organização Mundial da Saúde. Carta de Ottawa - Promoção da Saúde e Saúde Pública. Ottawa: Organização Mundial da Saúde; 1986.
41. Reis RS, Yan Y, Parra DC, Brownson RC. Assessing participation in community-based physical activity programs in Brazil. Med Sci Sports Exerc 2014; 46:92-8.

42. Costa BVL, Mendonça RD, Peixoto SV, Alves M, Lopes ACS. Academia da Cidade: um serviço de promoção da saúde na rede assistencial do Sistema Único de Saúde. Ciênc Saúde Coletiva 2013; 18 : 95-102.

43. Rose G. Sick individuals and sick populations. Int J Epidemiol 1985; 14:32-8.

44. Bond L, Egan M, Kearns A, Tannahill C. GoWell: the challenges of evaluating regeneration as a population health intervention. Prev Med 2013; 57:941-7.

Submitted on $07 / \mathrm{Jul} / 2014$

Final version resubmitted on 11/Nov/2014

Approved on 14/Nov/2014 